\section{On the Crystal Structure of a Tin(II) Bromide Hydrate, $2 \mathrm{SnBr}_{2} \cdot \mathrm{H}_{2} \mathrm{O}$ JAN ANDERSSON}

Department of Inorganic Chemistry, Chalmers University of Technology and the University of Göteborg, P.O. Box, S-402 20 Göteborg 5, Sweden

The crystal structure of a compound with the stoichiometric formula $2 \mathrm{SnBr}_{2} \cdot \mathrm{H}_{2} \mathrm{O}$ has been investigated, and preliminary results are presented in this communication.

Crystals of the compound were prepared by heating metallic tin with hydrobromic acid under reflux and then evaporating the solution. The crystals are unstable in air and rapidly lose water, becoming opaque.

X-Ray diffraction data $(h 0 l-h 3 l)$ were recorded with $\mathrm{Cu} K \alpha$ radiation using Weissenberg techniques. The crystals were found to be monoclinic with the following cell dimensions, as determined from Guinier powder diffraction data:

$$
\begin{gathered}
a=12.246 \AA, \quad b=4.298 \AA, \quad c=25.166 \AA, \\
\beta=101.40^{\circ}, \quad V=1298.4 \AA^{3}
\end{gathered}
$$

The unit cell contains 6 formula units. Possible space groups are No. 4, $P 2_{1}$ and No. $11, P 2_{1} / m .^{1}$

The main features of the structure were determined from a three-dimensional Patterson synthesis, by comparison with the structure of $3 \mathrm{PbBr}_{2} .2 \mathrm{H}_{2} \mathrm{O}^{2}$ The positions of the oxygen atoms were determined from a difference electron density map. Assuming the atoms to be situated in the point position $P 2_{1} / m: 2(e),{ }^{1}$ a least squares refinement on the $h 0 l$ and $h 1 l$ data yielded a preliminary $R$-value of $15.7 \%$. The structure is to be refined further with data from new crystals.

Fig. 1 shows a projection of the structure of $2 \mathrm{SnBr}_{2} \cdot \mathrm{H}_{2} \mathrm{O}$ on the $x z$ plane. Three different types of tin coordination occur in the crystals, namely $\mathrm{Sn}-8 \mathrm{Br}, \mathrm{Sn}-$ $7 \mathrm{Br}+1 \mathrm{H}_{2} \mathrm{O}$ and $\mathrm{Sn}-7 \mathrm{Br}$. The coordination figure, which is basically the same for all three types, consists of a trigonal prism

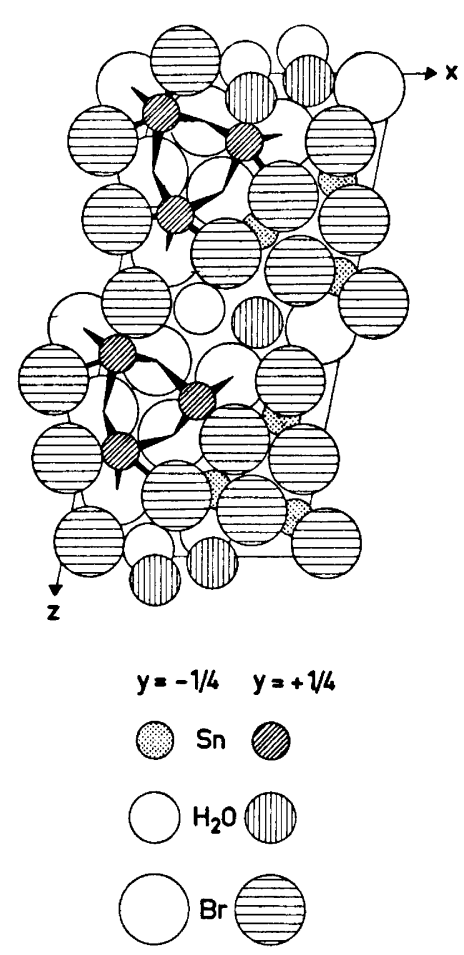

Fig. 1. A projection of the structure of $2 \mathrm{SnBr}_{2} \cdot \mathrm{H}_{2} \mathrm{O}$ on the $x z$ plane.

of bromine atoms with one or two additional atoms $\left(\mathrm{Br}, \mathrm{H}_{2} \mathrm{O}\right)$ outside prism faces.

The $\mathrm{Sn}-\mathrm{Br}$ distances range from $2.75 \AA$ to $3.70 \AA$ and the $\mathrm{Sn}-\mathrm{O}$ bond distance is $2.28 \AA$.

This work has been supported financially by the Swedish Natural Science Research Council, Contract No. 2318.

1. International Tables for X-Ray Crystallography, 2nd Ed., Kynoch Press, Birmingham 1952 , Vol. I.

2. Andersson, J. and Lundgren, G. Acta Chem. Scand. 24 (1970) 2670.

Received March 30, 1972. 